\title{
Equipe multiprofissional de saúde: a interface entre trabalho e interação
}

Estudamos o trabalho em saúde, com o objetivo de analisar as concepções de agentes sobre o sentido do trabalho em equipe multiprofissional e as evidências empíricas do caráter coletivo desse trabalho. Tomamos, como referencial teórico, os estudos do processo de trabalho em saúde e do agir comunicativo, buscando observar a dialética trabalho-interação no material empírico coletado. Realizamos a pesquisa de campo pela observação direta do cotidiano de trabalho em quatro situações distintas (enfermaria clínica e unidade de terapia intensiva, hospitalares; ambulatório de especialidades gerais e ambulatório de saúde mental) e por meio de entrevistas com profissionais inseridos nas equipes de trabalho. Partindo da definição de uma tipologia que distingue equipe agrupamento e equipe integração, $e$ analisando como se configuram os aspectos de complementaridade e interdependência dos trabalhos especializados, de articulação desses trabalhos, da autonomia técnica e da interação dos agentes, observamos que nas quatro situações estudadas os profissionais projetam a perspectiva da equipe integração, embora encontrem-se em situações de agrupamento, estando o ambulatório de saúde mental mais próximo do que denominamos equipe integração. Também observamos que a diferença técnica dos trabalhos especializados transmuta-se em desigualdade valorativa dos mesmos. $\mathrm{O}$ trabalho em equipe emerge como modalidade de trabalho coletivo que se configura na relação recíproca entre as intervenções técnicas e a interação dos agentes. No bojo da relação entre trabalho $e$ interação os profissionais constróem consensos que configuram um projeto assistencial comum, em torno do qual se dá a integração da equipe de trabalho.

\footnotetext{
Marina Peduzzi

Tese de Doutorado, 1998

Faculdade de Ciências Médicas

Universidade Estadual de Campinas
}

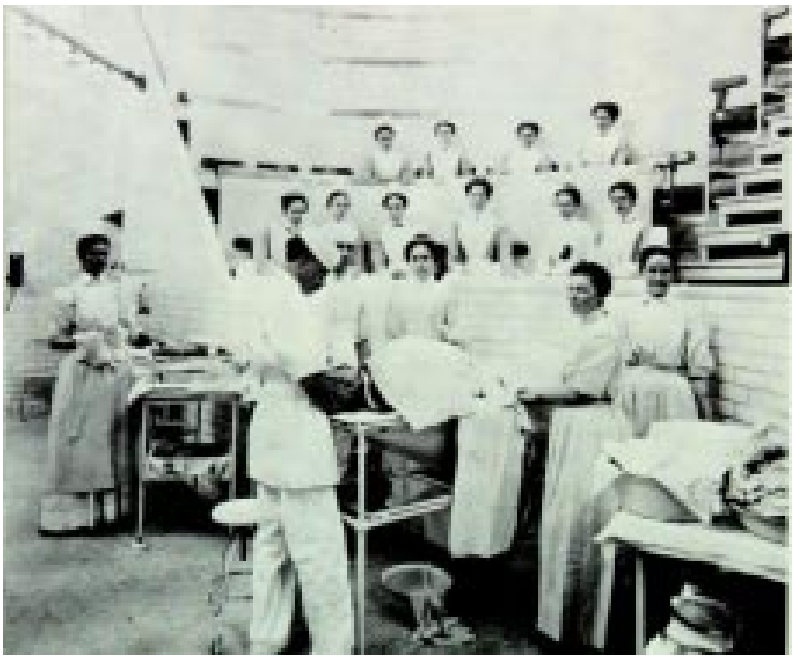

Treinamento de enfermeiras no St. Luka's Hospital, 1899. Museum of City of New York. 